\title{
RECONCEPTUALIZING NECESSITY ENTREPRENEURSHIP: A CONTEXTUALIZED FRAMEWORK OF ENTREPRENEURIAL PROCESSES UNDER THE CONDITION OF BASIC NEEDS
}

\begin{tabular}{|c|l|}
\hline Journal: & Academy of Management Review \\
\hline Manuscript ID & AMR-2017-0471-Original.R3 \\
\hline Manuscript Type: & Original Manuscript \\
\hline Topic Areas: & $\begin{array}{l}\text { Necessity < Entrepreneurship Opportunities < Entrepreneurship, } \\
\text { Creation < Entrepreneurship Opportunities < Entrepreneurship, } \\
\text { Discovery/Recognition < Entrepreneurship Opportunities < } \\
\text { Entrepreneurship }\end{array}$ \\
\hline Theoretical Perspectives: & Human capital theory, Social capital theory, Economic Sociology \\
\hline Abstract: & $\begin{array}{l}\text { Scholarly interest in necessity entrepreneurship has risen steadily over } \\
\text { the last four decades, with much of the research in this area focused on } \\
\text { distinguishing individuals who are pushed into entrepreneurship by } \\
\text { negative factors such as unemployment, from those who are pulled into } \\
\text { it by its attractiveness. Yet, although past research has extended } \\
\text { knowledge considerably, the dichotomous framing commonly employed } \\
\text { in studies in this realm has limited theoretical development, as it ignores } \\
\text { important variation among necessity entrepreneurs and, hence, the } \\
\text { processes by which they engage in entrepreneurship. In this paper, we } \\
\text { seek to reconceptualize the necessity entrepreneurship construct by } \\
\text { drawing on a motivational theory of necessity to predict how variation in } \\
\text { founders' basic needs influences the entrepreneurial process, conditional } \\
\text { on the level of their human capital endowments, the environmental } \\
\text { context in which they are embedded, and the presence of supportive } \\
\text { institutional levers. We conclude by discussing the implications of our } \\
\text { study and the potential ways in which our theory can be tested and } \\
\text { extended. }\end{array}$ \\
\hline
\end{tabular}


RECONCEPTUALIZING NECESSITY ENTREPRENEURSHIP:

A CONTEXTUALIZED FRAMEWORK OF ENTREPRENEURIAL PROCESSES

UNDER THE CONDITION OF BASIC NEEDS

\author{
John C. Dencker \\ Northeastern University \\ j.dencker@northeastern.edu \\ Sophie Bacq \\ Northeastern University \\ s.bacq@northeastern.edu \\ Marc Gruber \\ Ecole Polytechnique Fédérale de Lausanne \\ marc.gruber@epfl.ch \\ Melvin Haas \\ Asyril SA \\ melvin.haas@me.com
}

\begin{abstract}
Acknowledgments. We would like to thank our Editor Sharon Alvarez for her invaluable guidance and the three anonymous reviewers for their developmental and thoughtful feedback. We are thankful to all of those who graciously provided advice on previous versions of this manuscript: Joern Block, Juan Bravo, Roberto Fernandez, Tom Kochan, Robert Nason, Argyro Nikiforou, Paul Osterman, Chris Tucci, and Peter Vogel. This work also benefited greatly from discussions during presentations at The University of Cape Town, the Strategic Management Society Special Conference in Sydney, Australia, and the MIT - IWER Seminar.
\end{abstract}




\title{
RECONCEPTUALIZING NECESSITY ENTREPRENEURSHIP: \\ A CONTEXTUALIZED FRAMEWORK OF ENTREPRENEURIAL PROCESSES \\ UNDER THE CONDITION OF BASIC NEEDS
}

\begin{abstract}
Scholarly interest in necessity entrepreneurship has risen steadily over the last four decades, with much of the research in this area focused on distinguishing individuals who are pushed into entrepreneurship by negative factors such as unemployment, from those who are pulled into it by its attractiveness. Yet, although past research has extended knowledge considerably, the dichotomous framing commonly employed in studies in this realm has limited theoretical development, as it ignores important variation among necessity entrepreneurs and, hence, the processes by which they engage in entrepreneurship. In this paper, we seek to reconceptualize the necessity entrepreneurship construct by drawing on a motivational theory of necessity to predict how variation in founders' basic needs influences the entrepreneurial process, conditional on the level of their human capital endowments, the environmental context in which they are embedded, and the presence of supportive institutional levers. We conclude by discussing the implications of our study and the potential ways in which our theory can be tested and extended.
\end{abstract}

Keywords: Necessity entrepreneurship, level of need, unemployment duration, entrepreneurial process, human capital, environmental context, institutional levers 


\section{INTRODUCTION}

Scholarly interest in necessity entrepreneurship — generally conceived of as entrepreneurial activity arising out of need due to a lack of employment alternatives - has risen steadily over the past four decades (Brewer \& Gibson, 2014; Shapero, 1975, 1984), in no small part because this phenomenon offers a stark contrast to the oftentimes heroic depictions of entrepreneurs who, with great eagerness and strong ambition, pursue an opportunity for new wealth creation.

Necessity entrepreneurs, on the other hand, are pushed into entrepreneurial activity, creating new businesses that usually have limited growth potential and often replicating what other businesses are already offering (Dencker, Gruber, \& Shah, 2009a; Maas \& Herrington, 2006). Nevertheless, despite being much less glamorous, necessity entrepreneurship is highly prevalent (Institut für Mittelstandsforschung, 2005; Poschke, 2013; SCB, 1994) and generates positive outcomes around the world. For instance, evidence from Germany shows that firms founded by necessity entrepreneurs have fairly high survival rates, thereby providing a new basis for their own economic subsistence (BfE, 2004; Dencker, Gruber, \& Shah, 2009b).

Although necessity entrepreneurship research has produced important insights (Brewer \& Gibson, 2014; Vivarelli, 2013), our theoretical understanding remains sorely limited. That is, although the predominant conceptual account of necessity entrepreneurship - grounded in the push-pull framework - has drawn attention to the topic and highlighted critical factors pushing individuals to become entrepreneurs (Brockhaus, 1980; Evans \& Leighton, 1989; Giacomin, Guyot, Janssen, \& Lohest, 2011; Shapero, 1975, 1984; Shapero \& Sokol, 1982), it emphasizes a dichotomous view contrasting necessity entrepreneurs with opportunity entrepreneurs who are pulled into entrepreneurship by its attractiveness. In doing so, key distinctions among necessity entrepreneurs, the environments in which they operate, and the processes by which they engage 
in entrepreneurship are relegated to the background, away from scholars' attention. As a consequence, necessity entrepreneurs are often depicted homogeneously as low-skilled individuals creating small businesses (e.g., Poschke, 2013), leaving key variation that exists within necessity entrepreneurship underexplored and undertheorized.

Hence, we seek to advance theory on necessity entrepreneurship by addressing the questions of who necessity entrepreneurs are and how they engage in the entrepreneurial process. Specifically, we aim to reconceptualize the necessity entrepreneurship construct by relying on motivational theory (Carsrud \& Brännback, 2011; Maslow, 1954) and the concept of "basic needs" (Maslow, 1943: 372). This concept allows us to establish an elemental boundary condition, as individuals who start a venture to fulfill basic needs (e.g., purchase food, obtain security) will likely engage in a different entrepreneurial process than those seeking to fulfill higher-level needs. For instance, individuals who are focused on survival will likely experience a strong sense of urgency and ignore entrepreneurial opportunities with long payoff periods (Carsrud \& Brännback, 2011).

While individuals' motivation to fulfill basic needs through entrepreneurship forms the core of our theorizing, developing a profound understanding of the variation that exists within necessity entrepreneurship also requires consideration of individual and contextual differences that have been shown to affect entrepreneurship in general (e.g., Gartner, 1985; Shane, 2003; Welter, 2011) and necessity entrepreneurship in particular (e.g., Bradley, McMullen, Artz, \& Simiyu, 2012; Wennekers, Van Stel, Thurik, \& Reynolds, 2005). As Shane (2003: 3) notes, "neither the environment-centric nor the individual-centric approach toward entrepreneurship is more 'correct' than the other. Both probably explain equal amounts of the variance in entrepreneurial activity." As such, we consider how the level of human capital upon which 
founders are able to draw (low vs. high), the environments in which they operate (developing vs. developed), and the absence or presence of institutional levers supportive of entrepreneurial endeavors - which we define as agencies that seek to foster entrepreneurial activity and ease venture founding through the provision of various types of aid (e.g., McKague, Zietsma, \& Oliver, 2015; Mair, Martí, \& Ventresca, 2012)—influence entrepreneurship out of necessity.

Our study makes three main contributions to the literature. First, by reconceptualizing the necessity entrepreneurship construct, we establish a key boundary condition—fulfillment of basic needs - that enables scholars to cleanly delineate the phenomenon and study it in a theorydriven manner. By focusing on the entrepreneurial process in response to the fulfillment of basic needs, we explicitly address the "bottom part" in Maslow's hierarchy of needs, and complement past research examining the pursuit of higher-level needs (e.g., psychological and self-fulfillment needs) through entrepreneurship. Our reconceptualization, rooted in seminal human motivation theory, invites scholars to rethink the source of entrepreneurial motivations in terms of levels of need, and to revisit the entrepreneurial process across these levels of need. In other words, our claim that necessity entrepreneurs, in their attempts to fulfill basic needs, also engage in a process of opportunity identification and exploitation, challenges the assumption that the latter should only be the prerogative of opportunity entrepreneurs.

Second, we provide novel insights for contextualization approaches to entrepreneurship by accounting for key variation in both the human capital endowments of necessity entrepreneurs and the environmental contexts in which they operate to theorize about how these individual and environmental factors influence entrepreneurial processes under the condition of basic needs.

Our theorizing posits that individuals with similar levels of human capital will engage in different types of entrepreneurial processes when they are located in different environments to 
offer a more refined understanding of this heterogeneous phenomenon, thereby setting the stage for future studies on necessity entrepreneurs and their variation in venturing across contexts.

Third, by recognizing the role and importance of institutional levers that exist to support the endeavors of necessity entrepreneurs (McKague et al., 2015; Mair et al., 2012), we advance a theoretical perspective on necessity entrepreneurship that allows for institutional agency, thereby forging a close link between institutional research and the managerial and organizational literature (e.g., Aguilera \& Grøgaard, 2019). We do so by extending research on the supportive role of institutions in helping individuals involved in new venture creation, to argue conceptually about how the absence or presence of supportive institutional levers leads to starkly different entrepreneurial processes for otherwise similar necessity entrepreneurs.

\section{PRIOR RESEARCH ON NECESSITY ENTREPRENEURSHIP}

The extant literature on necessity entrepreneurship is quite heterogeneous, as it examines this widespread issue for a variety of personal characteristics (Bergmann \& Sternberg, 2007; Bhola et al., 2006; Giacomin, Janssen, \& Shinnar, 2018) and in a variety of environments (Acs, Desai, \& Hessels, 2008). These two elements - the individual and the environment - have been used to explain what pushes someone to become a necessity entrepreneur. That is, the vast majority of research in this realm has focused on the antecedents of necessity entrepreneurship. Yet, as we discuss below, scholars have also started to generate important evidence on the processes and outcomes of this widespread phenomenon.

First, past research on antecedents examines who creates ventures out of necessity (e.g., Block, Kohn, Miller, \& Ullrich, 2015) and the "specific conditions that lead people to take such a chance" (Shapero, 1975: 252). Echoing the general literature on human motivation and its longstanding differentiation between drive (internal stimulus) and incentive (external stimulus) 
motives (Festinger, 1957; Freud, 1924; Murray, 1938), Shapero $(1975,1984)$ provides an important conceptual building block for necessity entrepreneurship with his "push-pull" notion. In particular, he points out that the hardships one faces can provide an impulse (i.e., a "push") for becoming self-employed and that “( $\mathrm{m})$ ost entrepreneurs are displaced persons who have been dislodged from some nice, familiar niche, and tilted off course" (1975: 252)."

Drawing on these pioneering ideas, scholars have inquired into the multitude of factors that can explain such tilting off course. For instance, suffering from unemployment is regarded as a major determinant of the decision to become a necessity entrepreneur (Binder \& Coad, 2013; Block \& Wagner, 2010; Gilad \& Levine, 1986; Ritsilä \& Tervo, 2002), as is survival and fear of death (Carsrud \& Brännback, 2011). Importantly, the environment in which one is embedded plays a vital role in pushing individuals to act entrepreneurially, as indicated by the prevalence of necessity entrepreneurs in poorer countries (Naudé, 2010; Reynolds, 2012; Vivarelli, 2013). However, necessity entrepreneurship occurs and takes shape in environmental contexts regardless of level of development. For instance, Poschke (2013) estimates that necessity entrepreneurship is highly prevalent in both OECD and non-OECD countries, with rates amounting to $21.1 \%$ and $46.5 \%$, respectively.

Second, research on the processes of necessity entrepreneurship is scant, although studies in similar areas point to critical factors such as human capital endowments upon which necessity entrepreneurs can draw, and the various environments in which they operate (Brewer \& Gibson, 2014; Gruber, 2010). For instance, studies of low-skilled entrepreneurs at the bottom of the pyramid (e.g., Bruton, Ketchen, \& Ireland, 2013; Hall, Matos, Sheehan, \& Silvestre, 2012; Khavul, 2010; Kistruck, Webb, Sutter, \& Ireland, 2011; Mair \& Martí, 2009; Mair et al., 2012; Seelos \& Mair, 2007) highlight the singular challenges faced by entrepreneurs in poverty—most 
of whom are pushed to entrepreneurship by necessity rather than by choice-but often do not delve deeply into the processes by which these individuals identify business opportunities and exploit them (see Alvarez \& Barney, 2014, and Nikiforou, Dencker, \& Gruber, 2019 for exceptions). Moreover, as scholars have noted, the nature of the opportunity in much of this research is often either ignored or viewed in simplistic ways, with necessity entrepreneurs seeking to exploit self-employment opportunities that replicate those existing in their local context (Alvarez \& Barney, 2014; Matin, Hulme, \& Rutherford, 2002; McMullen, Bagby, \& Palich, 2008). By contrast, even developed countries with strong markets are replete with highly educated individuals facing pressures to become necessity entrepreneurs, such as experienced managers and professionals who were laid off during corporate restructurings, and highly educated graduates who are unable to find jobs (Cappelli et al., 1997; Dencker, 2012). ${ }^{1}$ Yet, both theoretical developments and empirical evidence of the likely varied processes in which necessity entrepreneurs with different skillsets in different contexts engage are scarce in the extant literature.

Finally, research on outcomes has examined job creation and survival rates of firms founded by necessity entrepreneurs, as well as the income and sales revenues they generate (Block \& Sandner, 2009; Caliendo \& Kritikos, 2010; Dencker \& Gruber, 2015; Dencker et al., 2009a, 2009b; Santarelli \& Vivarelli, 2007; Shane, 2009). Most of these studies focus on developed nations to show, for instance, that a third of new firms founded by the unemployed in Germany created at least one job in addition to the founder, and two-thirds survived in the first

\footnotetext{
${ }^{1}$ Statistics show that while most necessity entrepreneurs have between one and eleven years of schooling, among those with 12 years of schooling, $24.9 \%$ are necessity entrepreneurs (39.5\% in non-OECD countries). These statistics indicate that not all necessity entrepreneurs have low levels of human capital (Poschke, 2013).
} 
four years after launch — thereby enabling many necessity entrepreneurs to develop a new basis for their own subsistence (BfE, 2004; Dencker et al., 2009b). Although research on outcomes of necessity entrepreneurship in impoverished settings — where individuals are in dire need of employment opportunities and sustainable livelihoods - remains rare (Kolk, Rivera-Santos, \& Rufín, 2014; Vivarelli, 2013), it has provided important insights. For example, in a recent qualitative study, Tobias, Mair, and Barbosa-Leiker (2013) unpack mechanisms through which entrepreneurial processes increased the quality of life of entrepreneurs in the Rwandan coffee industry.

In sum, the literature on necessity entrepreneurship emphasizes its antecedents more than its processes and outcomes, with research focusing primarily on negative individual and contextual factors pushing individuals into entrepreneurship. Yet, this overemphasis on push factors - while used to define the essence of necessity entrepreneurship — has led scholars to draw binary comparisons between necessity entrepreneurs who are pushed to entrepreneurship (internally driven by negative factors), and those who are pulled to it (externally incentivized by opportunities). It is thus evident that a more systematic approach to theorizing is required to elicit the richness of necessity entrepreneurship and the multiplicity of processes it entails. We seek to fill this critical knowledge gap by offering a reconceptualization of necessity entrepreneurship that is anchored in an unambiguous boundary condition of basic needs, thereby allowing us to portray a more diverse picture of this important and growing phenomenon.

\section{RECONCEPTUALIZING NECESSITY ENTREPRENEURSHIP AS ENTREPRENEURSHIP UNDER THE CONDITION OF BASIC NEEDS}

To systematically address the questions of who necessity entrepreneurs are and how they engage in the entrepreneurial process, we reconceptualize the notion of necessity entrepreneurship 
through the lens of motivational theory by building on need fulfillment notions evident in Maslow's $(1943,1954)$ hierarchy of needs framework. Maslow's hierarchy is comprised of five levels of need, ranging from lower to higher levels as follows: physiological, safety, belongingness and love, esteem, and self-actualization needs. These five levels of need have been further grouped into three main categories: first, basic needs comprise both physiological (e.g., food and water) and safety (e.g., security and basic financial) needs; second, psychological needs comprise belongingness and love, and esteem; and third, self-fulfillment needs correspond to self-actualization needs (Maslow, 1954).

We draw on Maslow's foundational framework to reconceptualize the necessity entrepreneurship construct, which we define as venture creation activities by individuals who seek to fulfill their basic physiological and safety needs. In this vein, necessity entrepreneurs start a venture in order to have access to food and water, and to fulfill their basic security and financial needs. Because these two basic needs differ in considerable ways, we expect that the entrepreneurial process will also vary by the type of need. For instance, the urgency surrounding new venture creation is arguably stronger for the fulfillment of physiological (as opposed to safety) needs, implying considerable differences across the two need types in the amount of time that can be dedicated to the entrepreneurial process.

In adopting this framework, we conceive of entrepreneurial motivations as lying along a continuum: while necessity entrepreneurs are those who start a venture out of basic needs, other types of entrepreneurs will do so in order to fulfill higher-level needs. ${ }^{2}$ Indeed, foundational

\footnotetext{
${ }^{2}$ Scholars have noted that need fulfillment in Maslow's hierarchy does not always follow in a lock-step progression, with lower-level needs having to be fulfilled before an individual seeks to fulfill higher-level needs (e.g., Neher, 1991). For example, in contrast to this assumption, individuals may seek to fulfill belongingness needs and esteem
} 
writings on entrepreneurial motivation focusing on the psychological differences that demarcate entrepreneurs from non-entrepreneurs (Carsrud \& Brännback, 2011) tend to restrict the former to individuals who engage in entrepreneurship to fulfill higher-level needs, that is, psychological and self-fulfillment needs. For instance, McClelland (1961, 1987) argues that entrepreneurs distinguish themselves from non-entrepreneurs by their need for achievement - a strong desire to assume personal responsibility, to set and meet moderately difficult goals, and to receive performance feedback. In other words, McClelland's framework considers entrepreneurs to be those who seek to fulfill esteem needs in Maslow's (1954) sense, thereby excluding individuals with lower-level needs who nevertheless engage in entrepreneurship.

In sum, we seek to fill critical gaps in necessity entrepreneurship research by examining variation in entrepreneurial behavior under the boundary condition of basic needs. At the core of our theorizing lies the notion that necessity entrepreneurs who start a venture to fulfill basic needs engage in a different entrepreneurial process than those seeking to fulfill higher-level needs. Moreover, we expect key differences in entrepreneurial processes when necessity entrepreneurs are driven either by their most basic needs (e.g., access to food, water), or by the next higher level of basic needs (e.g., security, stability).

\section{VARIATION IN ENTREPRENEURIAL PROCESSES UNDER THE CONDITION OF BASIC NEEDS}

\footnotetext{
needs at the same time. We acknowledge this issue, but argue that it is less likely to occur for basic needs, and, even in the cases where it does, the lower-level needs will have the greatest relative effect on behavior. For instance, if an individual is seeking to fulfill physiological needs, he or she will be hard pressed to try to fulfill belongingness needs, as "(F)ailing could mean death, a risk not worth taking” (Carsrud \& Brännback, 2011: 15). In the discussion section, we consider what relaxing this strict assumption would mean for the entrepreneurial process.
} 
In the following, we develop theory on how heterogeneity among necessity entrepreneurs leads to variation in the entrepreneurial process. Therefore, a key issue to consider is what determines the type of need that an individual seeks to fulfill, which at its heart is whether an individual has access to resources - thereby highlighting the critical importance of the environment and the support it provides to those in need. In particular, the resources to which an individual has access vary considerably across environments, being scarce in developing environments, and abundant in developed ones. ${ }^{3}$ Given that developing environments often have weak social safety nets, the lack of resources in these settings suggests that the majority of necessity entrepreneurs will be seeking to fulfill their most basic needs for food, water, etc. That is, it seems likely that the average necessity entrepreneur in a developing environment will be engaging in entrepreneurship in order to fulfill physiological needs. By contrast, in developed environments, resources are more abundant, and welfare states typically provide sufficient support to allow individuals to fulfill their physiological needs. As such, we argue that the average necessity entrepreneur in developed settings will be seeking to fulfill safety needs in order to obtain security and stability.

Following this reasoning, we develop two sets of propositions that advance our understanding of the entrepreneurial process when necessity entrepreneurs are driven by their basic needs - either under the condition of physiological needs in developing environments, or

\footnotetext{
${ }^{3}$ We acknowledge that the dichotomy of developing versus developed nations has limitations (Rosling, Rosling, \& Rosling Rönnlund, 2018), as there is greater nuance in countries' developmental status than this dichotomy suggests. As we discuss in-depth later in this article, although we do not exclude the possibility that individuals in developed settings have to fulfill their the most basic needs for food, water, and shelter, our arguments are grounded in the evidence that in richer, more resourceful environments, a safety net, such as in the form of food stamps and affordable housing, may alleviate some of the most basic needs for these individuals. Further, by referring to environments and environmental contexts, we account for heterogeneity that (may) exist within and across nations.
} 
under the condition of safety needs in developed environments. We further refine our theorizing by adopting a contextualized framework (Shepherd, 2011; Welter, 2011; Welter \& Smallbone, 2011) that draws on neo-classical economic (Becker, 1964) and institutional notions (North, 1990). In particular, we consider how key individual and environmental factors shape the entrepreneurial processes of different necessity entrepreneurs.

First, we argue that a necessity entrepreneur's level of human capital endowments will have a critical influence on the entrepreneurial process (e.g., Davidsson \& Honig, 2003; Unger, Rauch, Frese, \& Rosenbusch, 2011). However, we do not theorize about human capital in a vacuum, but rather in relation to the nature of the environmental context in which necessity entrepreneurs are situated. At the opportunity identification stage (Choi, Lévesque, \& Shepherd, 2008), our contextualized framework advances that an individual's stock of prior knowledge and experience will likely affect the opportunities that he or she identifies (Alvarez \& Barney, 2014; Gruber, 2010; Ucbasaran, Westhead, \& Wright, 2008, 2009). Yet, the nature of these opportunities will vary in key ways across developed and developing environments, such as in terms of their number and potential value (Gruber, 2010). At the opportunity exploitation stage, human capital endowments will likely affect resource acquisition, the bundling of resources into capabilities, and the leveraging of capabilities into value creation and capture (Sirmon, Hitt, \& Ireland, 2007; Sutter, Bruton, \& Chen, 2018). However, necessity entrepreneurs' ability to do so will be more constrained in developing environments characterized by restricted market structures, as compared to developed ones.

Second, we argue that the way that necessity entrepreneurs engage in the entrepreneurial process in a given environment depends on the absence or presence of supportive institutional levers, which we defined above as agencies that seek to foster entrepreneurial activity and ease 
venture founding through the provision of various types of aid. We focus on two main types of levers - intermediary organizations (e.g., Dutt, Hawn, Vidal, Chatterji, McGahan, \& Mitchell, 2016; Mair et al., 2012), and government programs (Haas \& Vogel, 2016). For example, in developing environments, finance providers such as microfinance institutions provide small loans that help entrepreneurs get started (Chliova et al., 2015; Helms, 2006; Morduch, 2000), while assisting and capacity-building institutions provide training to those at the bottom of the economic pyramid (Mair et al., 2012; McKague et al., 2015). In developed environments, government-sponsored programs designed to help the unemployed transition to entrepreneurship offer financial support and training to participants (Haas \& Vogel, 2016).

We maintain that institutional levers supportive of entrepreneurship will have two common effects on necessity entrepreneurs across environmental contexts: (1) by providing financial support, they increase the amount of time these individuals can dedicate to the entrepreneurial process and the types of opportunities they can exploit, and (2) by providing training and capacity building support, they help necessity entrepreneurs to obtain new skillsets, and increase their ability to use their existing skills more effectively.

In a nutshell, our first set of propositions $(\mathrm{P} 1 \mathrm{a} / \mathrm{b}, \mathrm{P} 2 \mathrm{a} / \mathrm{b})$ examines necessity entrepreneurs embedded in developing environments seeking to fulfill the most basic level of needs (access to food, etc.), and explores variation in the entrepreneurial process as a function of their level of human capital endowments and the absence or presence of supportive institutional levers. We repeat this setup for our second set of propositions $(\mathrm{P} 3 \mathrm{a} / \mathrm{b}, \mathrm{P} 4 \mathrm{a} / \mathrm{b})$, where we investigate the entrepreneurial process of necessity entrepreneurs embedded in developed environments seeking to fulfill the next higher level of basic needs (safety in the form of financial security, etc.), again conditional on their level of human capital endowments, and the absence or presence of 
supportive institutional levers. Figures $1 \mathrm{a}$ and $1 \mathrm{~b}$ provide a systematic overview of our two sets of propositions. ${ }^{4}$

\section{Insert Figures $1 \mathrm{a}$ and $1 \mathrm{~b}$ about here}

\section{Physiological Needs and the Entrepreneurial Process \\ Low levels of human capital endowments in a developing environment. Individuals} seeking to fulfill physiological needs of food, water, etc. are likely the most common type of necessity entrepreneurs globally, as they reside at the bottom of the economic pyramid (Bruton et al., 2013; Hall et al., 2012; Khavul, 2010; Kistruck et al., 2011; Kolk et al., 2014). Such necessity entrepreneurs are exemplified by Banerjee and Duflo (2007: 162) who observe, based on an in-depth analysis of the poor's economic lives in thirteen developing countries, that:

"If you have few skills and little capital... being an entrepreneur is often easier than finding an employer with a job to offer. You buy some fruits and vegetables or some plastic toys at the wholesalers and start selling them on the street; you make some extra dosa mix and sell the dosas in front of your house; you collect cow dung and dry it to sell it as a fuel; you attend to one cow and collect the milk. These types of activities are exactly those in which the poor are involved."

A myriad of individuals living in such conditions often face a two-fold challenge: first, their skills are generally low and, second, the developing environments in which they are embedded offer few employment options (Alvarez \& Barney, 2014). Moreover, this challenge is magnified when there is an absence of supportive institutional levers in the environment (Karnani, 2007).

\footnotetext{
${ }^{4}$ Although the types of necessity entrepreneurs that we consider do not portray all variation in this regard, we argue that they capture a considerable proportion of such individuals.
} 
We argue that these necessity entrepreneurs, who create small sole-proprietor businesses simply to survive (Vivarelli, 2013), do so by engaging in a replication entrepreneurial process. That is, driven by physiological needs, these entrepreneurs will think of almost an exact copy of the business idea that they can observe in close proximity to where they live, and that provides them with immediate financial gratification (Bradley, McMullen, Atmadja, Simiyu, \& Artz, 2011). These "replication opportunities" (Alvarez \& Barney, 2014) tend to be general rather than specialized in terms of the skills they require, and tend to offer products or services that are commercialized in fairly constrained market structures. The pursuit of these opportunities leads, for instance, to the creation of microbusinesses such as food retail (Charman \& Petersen, 2017), goat-milking and farming activities (Alvarez \& Barney, 2014), microfranchising (Kistruck et al., 2011; Webb \& Fairbourne, 2016) and other relatively basic services such as hair salons, shoe repair, small internet cafes, and cooking and laundry services. ${ }^{5}$ Case in point, a recent study of close to 1,800 microenterprise activities in South African townships suggests that new businesses tend to be restricted to five main activities: out of 21 different activities documented in the townships, takeaway food, micro retail stores, street trade, liquor sales, and house shops together represent 42 percent of all businesses serving a heterogeneous population of more than 43,000 people (Charman \& Petersen, 2017).

The individual-level attributes and the nature of the institutional contexts in which bottom-of-the-pyramid necessity entrepreneurs are located tend to preclude them from fulfilling their unmet physiological needs by pursuing non-replication opportunities. Indeed, the information to which these individuals have access is minimal, and circumscribed by informal institutions in the environment (Kuechle, Boulu-Reshef, \& Carr, 2016; Vaghely \& Julien, 2010).

\footnotetext{
${ }^{5}$ We thank one of our reviewers for suggesting these examples.
} 
Thus, in contrast to entrepreneurs with higher-level needs who engage in opportunity discovery, it is very unlikely that these necessity entrepreneurs will deliberately look for competitive imperfections in the local environment (Alvarez \& Barney, 2007; Kirzner, 1973). Further, it is also unlikely that they can create knowledge and information through incremental actions (Banerjee \& Duflo, 2007; Galbraith, 1977), and then integrate new knowledge and adapt it to new situations (Lazear, 2005) from which opportunities emerge iteratively (cf. opportunity creation, Alvarez \& Barney, 2007).

The replication logic pursued by these necessity entrepreneurs will not only be evident in the types of opportunities they identify, but also in the way in which they exploit them. Given their strong urge to satisfy physiological needs, they likely replicate the established practices of the ventures they are able to observe in their setting. In particular, because these businesses tend to be fairly simple in their set-up and operations, necessity entrepreneurs can understand what works for others running the same business, and can copy their practices (e.g., product design, scope of service offerings, resource acquisition, sales practices). Furthermore, one needs to consider the high costs of erecting barriers to mimetic actions. For instance, such barriers tend not to exist in these constrained market structures which are characterized by weak and ineffective formal institutions (e.g., lacking property rights enforcement) (Kistruck et al., 2011; McMullen et al., 2008; Prahalad, 2006; Webb, Bruton, Tihanyi, \& Ireland, 2013), thereby facilitating replication (Barney, 1991; Mostafa \& Klepper, 2013). Against the backdrop of these arguments, we propose that:

Proposition 1a: Under the condition of basic physiological needs in developing environments, necessity entrepreneurs with low levels of human capital will pursue a replication entrepreneurial process when supportive institutional levers are absent. 
Our theorizing about replicative forms of entrepreneurial behavior is based on the absence of institutional levers supportive of entrepreneurship. Yet, these levers do exist in developing environments, commonly in the form of intermediary organizations that help shape market exchanges of goods and services and offer a variety of financial and skill-based support to individuals in need (Dutt et al., 2016; Mair et al., 2012; McKague et al., 2015). For instance, microfinance institutions contribute both to market development, by remedying a weak banking system that inhibits financing of new ventures (cf. Dutt et al., 2016), and to individual development, by providing small loans at low interest rates and asset-based financing to necessity entrepreneurs (Chliova et al., 2015; Helms, 2006; Morduch, 2000). In addition, capacity-building institutions combining support specific to a given setting (e.g., livestock, agriculture) with general skill development (e.g., leadership, marketing and sales) (Mair et al., 2012; McKague et al., 2015) provide critical assistance to bottom-of-the pyramid necessity entrepreneurs, as do initiatives that teach a proactive entrepreneurial mindset (Campos et al., 2017).

We argue that supportive institutional levers will have a strong influence on the nature of the entrepreneurial process. In particular, we maintain that they will encourage bottom-of-the pyramid necessity entrepreneurs to pursue an experiential replication entrepreneurial process that is distinct from the replication rationale laid out above. In particular, institutional levers will encourage necessity entrepreneurs to identify a broader range of opportunities, and to engage in trial and error behavior during the exploitation stage. To better understand the effect of supportive institutional levers on the entrepreneurial process, it is important to consider the two developmental levels at which they operate (Dutt et al., 2016). 
At the market development level, levers help shape the exchange of goods and services, and foster market-based entrepreneurial activities (Venkataraman, Vermeulen, Raaijmakers, \& Mair, 2016). In addition, by reducing the uncertainty characteristic of weak market institutions in developing environments (Dutt et al., 2016; Mair et al., 2012; Webb et al., 2009), supportive institutional levers help necessity entrepreneurs consider a broad range of replication opportunities that are less common in their context, or that might exist in other contexts. In particular, levers may demonstrate that opportunities present in other settings can provide a way of fulfilling physiological needs by addressing latent, unfulfilled customer demand. For instance, instead of engaging in a replication entrepreneurial process by becoming the next among countless cell phone dealers on the street, necessity entrepreneurs could be nudged by the supportive institutional lever to open the first bike rental shop in their community, thereby enabling novel forms of transport in their impoverished setting. In effect, institutional levers encourage experiential behavior by expanding the range of opportunities necessity entrepreneurs can observe and therefore consider.

At the individual development level, institutional levers provide training and financial support to necessity entrepreneurs - thus increasing their cognition when it comes to considering opportunities and their ability to run a venture. For instance, microfinance institutions not only offer funding, but also provide rudimentary training about running a business (Karlan \& Valdivia, 2011). They therefore enable necessity entrepreneurs to better understand basic economic relationships, learn about any shortcomings that their initial business concept may have, and make more informed venture-related decisions. This is exemplified by the actions of CARE, the international development program whose aim is to combat global poverty by providing support to nascent entrepreneurs. For instance, McKague and colleagues' (2015) study 
of a CARE program seeking to foster market creation in low income rural areas in Bangladesh, uncovered critical benefits from the funding of experimental behavior in that it allowed entrepreneurs to see proof that the new practices and opportunities to which they were introduced would be effective in fulfilling their basic physiological needs. In other words, such trial and error behavior enables bottom-of-the-pyramid necessity entrepreneurs to consider replication opportunities in an experiential manner in order to establish greater fit between the venture offerings and the limited, unmet customer demand in the confined market structures in developing environments. As a result, these necessity entrepreneurs may act upon opportunities that have higher potential for economic merit, a non-trivial factor given the unmet and urgent physiological needs these individuals face.

In sum, we argue that supportive institutional levers help reduce contextual uncertainty in developing environments, and help bottom-of-the-pyramid necessity entrepreneurs observe a broader range of replication opportunities than they would in the absence of these levers. In addition, the levers will encourage these necessity entrepreneurs to engage in the entrepreneurial process in a more experiential way than they otherwise would, for instance by engaging in trial and error behavior. Stated more formally, we propose that:

Proposition 1b: Under the condition of basic physiological needs in developing environments, necessity entrepreneurs with low levels of human capital will pursue an experiential replication entrepreneurial process when supportive institutional levers are present.

High levels of human capital endowments in a developing environment. Although the majority of necessity entrepreneurs seeking to fulfill physiological needs in developing contexts have low skill levels (Banerjee \& Duflo, 2007), many possess high skill levels (Poschke, 2013). As examples, consider highly educated individuals (e.g., scientists, technicians) who find 
themselves unemployed after a civil war has eroded the economic basis of their country, highly educated immigrants fleeing famine- or conflict-stricken areas who are pushed to start a venture in the developing context where they land, or individuals with relatively high levels of education who are unable to find employment. In other words, for reasons spanning from political transformation to economic instability, these individuals must look to entrepreneurship as a way to fulfill their physiological needs, in no small part because the developing environments where they are located do not provide a social safety net.

We contend that these necessity entrepreneurs will engage in a skill-preserving entrepreneurial process that will prime them to identify opportunities in light of the varied applicability of their high human capital endowments (Shane \& Venkataraman, 2000). In particular, one of the biggest challenges these individuals face is that some of their hard-earned skills are devalued. That is, although necessity entrepreneurs would aim to capitalize on the skills they have acquired through higher education (e.g., educated to be an accountant, a scientist) and work experience (e.g., in a technical job), they often are not in a position to do so because they are in an environment characterized by limited market demand for their specialized and technical skills. Nevertheless, by virtue of their training and experience, these necessity entrepreneurs possess other skills that are applicable in a variety of ventures. For example, even though there may be no demand for accounting service firms in a market, an accountant can draw on math and reasoning skills in engaging in the entrepreneurial process. In other words, necessity entrepreneurs with high levels of human capital will seek to engage in entrepreneurial processes that allow them to utilize the skills that still have value in the market.

We argue that, in order to preserve some of their skills, and in the face of urgency that goes along with fulfilling physiological needs, necessity entrepreneurs with high human capital 
endowments will tend to copy business ideas of which they are aware. This entrepreneurial process will differ in two key ways from the one pursued by their counterparts with low levels of human capital (Proposition 1a). First, at the opportunity identification stage, the human capital endowments of these entrepreneurs will allow them to identify a larger range of opportunities. For example, their knowledge of potentially viable businesses will not be restricted to the local market, as their schooling and work experience likely exposed them to ideas and ventures not offered in the focal market. At the same time, they will take into account that some opportunities will allow them to employ their skills more effectively than will other opportunities. In short, these necessity entrepreneurs will be able to identify a range of ventures that are common and uncommon in their local market and will pursue ones that allow them to make most effective use of their generally applicable skills.

Second, at the opportunity exploitation stage, we argue that these necessity entrepreneurs will draw on their generally applicable human capital. For example, the strong cognitive capacities they obtained from education and experience will enable them to observe other ventures and learn from their operations, even if these other ventures are active in different domains. They will therefore take into account a multitude of observations and feedback when developing and operating their ventures. Furthermore, their stronger cognitive capacities also allow them to reflect on their course of action and to adapt their operations if necessary. In effect, in the face of strong pressures to fulfill physiological needs in a developing environment, these necessity entrepreneurs will not be able to draw on all of their acquired skills due to limited demand for them, yet they will nevertheless be able to draw on more generally applicable skills while identifying and exploiting opportunities. In sum, we propose that: 


\section{Proposition 2a: Under the condition of basic physiological needs in developing environments, necessity entrepreneurs with high levels of human capital will pursue a skill-preserving entrepreneurial process when supportive institutional levers are absent.}

As above, we maintain that the entrepreneurial process will vary considerably based on the absence or presence of supportive institutional levers, even more so in this situation where necessity entrepreneurs can distinguish themselves by their high levels of education and skills. Specifically, in settings where supportive institutional levers exist, necessity entrepreneurs with high levels of human capital may benefit from the assistance provided to them in engaging in a skill-leveraging entrepreneurial process that departs from the skill-preserving entrepreneurial process discussed above in non-trivial ways.

At the market-development level, a key issue to consider is that developing environments often suffer from voids in commercial institutions, and as such do not have the necessary structures and systems (e.g., regulations and business capabilities) to foster effective entrepreneurial activity (Dutt et al., 2016). Along the lines of uncertainty discussed earlier in Proposition 1b, we argue that supportive institutional levers will render start-up conditions in these settings more stable, by filling these market voids. For example, intermediary organizations can serve as catalysts for expanding ventures beyond the otherwise limited local market demand, thereby affording necessity entrepreneurs with high levels of human capital the ability to capitalize on their skills — as opposed to seeking to merely preserve them as is the case when institutional levers are absent (Proposition 2a).

Supportive institutional levers at the individual level will also help high-skilled necessity entrepreneurs to leverage their skills by providing financial and capacity building support. By providing financial support, levers increase the number of opportunities that necessity entrepreneurs can exploit, and thereby increase the likelihood that they can find a match with 
their skills. For example, such support could allow these individuals to open businesses that require some capital expenditures (e.g., purchasing equipment), which they would not be able to do in the absence of these levers. By providing skill training, levers can also help necessity entrepreneurs leverage their skills in a number of ways. For instance, given that the level of human capital is reflective of cognitive ability and knowledge structures (Gagné \& Glaser, 1987; Pelled, 1996), capacity building support will allow necessity entrepreneurs to build on and augment their already existing human capital assets by enabling them to acquire a more thorough understanding of the entrepreneurial process, and by helping them understand how they can leverage their skills in the constrained context in which they find themselves.

In sum, we argue that, as supportive institutional levers develop markets and elevate skillsets and entrepreneurial cognition, necessity entrepreneurs will seek to fulfill their basic physiological needs by pursuing opportunities that directly build on their skills, as opposed to copying ideas and businesses that already exist while preserving their skills. In effect, whereas institutional levers in developing environments encourage necessity entrepreneurs with low human capital endowments to look for shortcuts on well-trodden paths, such levers encourage those with high human capital endowments to take the road less traveled. Stated more formally, we propose that:

Proposition 2b: Under the condition of basic physiological needs in a developing environment, necessity entrepreneurs with high levels of human capital will pursue a skill-leveraging entrepreneurial process when supportive institutional levers are present.

\section{Safety Needs and the Entrepreneurial Process}

The above theory section highlights that developing environments typically do not provide the necessary resources for individuals to fulfill their physiological needs, regardless of their level of human capital endowments. By contrast, in developed environments, these most 
basic needs are often met due to the existence of welfare state programs. Nevertheless, whereas necessity entrepreneurs in developed environments tend to have advantages (e.g., welfare assistance) that their brethren in developing environments typically do not have, they face a variety of circumstances - such as limited employment opportunities - that push them to create businesses in order to fulfill their basic safety needs. We maintain that these safety needs will have an important influence on the new venture creation process of necessity entrepreneurs in developed environments, conditional on their human capital endowments, and the absence or presence of institutional levers supportive of their entrepreneurial endeavors (cf. Figure 1b).

Low levels of human capital endowments in a developed environment. In Proposition 1a we suggested that individuals with low levels of human capital in a developing environment will engage in a replication entrepreneurial process. Developed environments, by contrast, tend to offer resources to fulfill physiological needs, and offer a more munificent setting in which to create new ventures - yet, they do not guarantee that their basic safety needs are met. We argue that in order to fulfill such security and stability needs, necessity entrepreneurs with low human capital endowments will engage in an imitation entrepreneurial process that allows them to utilize the low levels of skills they acquired during required schooling, and to mimic the actions of similarly low-skilled founders. In this regard, it is important to note that the range of opportunities that necessity entrepreneurs can imitate in a developed setting is more expansive than in a developing setting, because market structures are less constrained and more heterogeneous. As such, the ventures necessity entrepreneurs in developed environments seek to create are neither exact replicas of other opportunities in the local market, nor are they necessarily run in the same way, even though they may share operational features. 
In terms of opportunity identification, necessity entrepreneurs' urge to fulfill basic safety needs, combined with their basic education and prior work experience in low-skill jobs (Hanson, Liu, \& McInstosh, 2017), will translate into the vetting of opportunities that favor financial gratification (Bradley et al., 2011) and that require little financial investment. Nevertheless, the refined market structures in which these entrepreneurs operate imply demand for a broad range of products and services. Therefore, we argue that they will identify opportunities based on the constrained amount of information and skills to which they have access, leading them to establish sole proprietorships involving delivery or sale of basic services or products in industries or activities commonly known to generate profit fairly quickly.

We also argue that such mimicking behavior will extend to the opportunity exploitation stage. In particular, low-skilled necessity entrepreneurs will draw inspiration from the business activities in which others with similar skillsets have engaged, and will imitate their practices and solutions. For example, these individuals might run their small cleaning service company, modest handyman sole proprietorship, or small eatery, in ways that imitate other service companies' operations in that market (e.g., in terms of the range of services or products being offered, or their promotional activities).

In sum, we maintain that these necessity entrepreneurs will engage in an entrepreneurial process that imitates other business operations that are observable in, and enabled by, their economic settings and market structures, and will imitate the behavior of other similar entrepreneurs in these settings. Stated more formally, we propose that:

Proposition 3a: Under the condition of basic safety needs in a developed environment, necessity entrepreneurs with low levels of human capital will pursue an imitation entrepreneurial process when supportive institutional levers are absent. 
As noted, the nature of the entrepreneurial process is conditional on whether institutional levers supportive of entrepreneurship exist. We claim that in the presence of supportive institutional levers, low-skilled necessity entrepreneurs in developed environments will pursue a differentiation entrepreneurial process. In particular, we propose that these levers will enable necessity entrepreneurs to leverage their (albeit limited) capabilities and skills to identify and exploit opportunities present in developed environments in ways that distinguish their business ideas from existing offerings.

In developed environments, governmental programs that seek to help individuals transition from unemployment to self-employment (Haas \& Vogel, 2016) are a common institutional lever. A key feature of these entrepreneurship supporting programs is that they afford participants time to craft value propositions around their business ideas, as well as to organize and launch their ventures (e.g., Dencker et al., 2009a). For example, governmentsponsored entrepreneurship training may pave the way to novel considerations of what an entrepreneurial opportunity is, where to acquire necessary resources, how to bundle them into unique capabilities, and how to operate the business in competitive settings. As such, these necessity entrepreneurs are less likely to approach the entrepreneurial process primed to imitate whatever exists in their surroundings, but rather to differentiate their offerings.

Institutional levers in developed environments may also help necessity entrepreneurs, through training and skill development, to conceive of a broader and more expansive range of opportunities than they would in the absence of these levers. For example, government programs may help necessity entrepreneurs tap into larger networks of reference to know what works and what does not work, augmenting their knowledge and cognition about the entrepreneurial process in the particular settings where they are situated (Haas \& Vogel, 2016). As a result, these 
levers help channel what necessity entrepreneurs know and what they can do into a different path than the imitative one, leading to unique offerings and/or different customer segments.

Taken together, supportive institutional levers will provide entrepreneurs access to larger networks of reference, allow them more time to differentiate unique value propositions around their business ideas, and enhance their low human capital levels through entrepreneurship training and skill development. In short, these levers will lead necessity entrepreneurs to engage in an entrepreneurial process that will allow them to differentiate their ventures from other similar ones in the market. Stated more formally, we propose that:

Proposition 3b: Under the condition of basic safety needs in a developed environment, necessity entrepreneurs with low levels of human capital will pursue a differentiation entrepreneurial process when supportive institutional levers are present.

High levels of human capital endowments in a developed environment. Necessity entrepreneurs with high levels of human capital endowments in developed settings obtained their skills through multiple years of schooling and work experience. Yet, they are pushed to create firms to fulfill safety needs, often because they were laid-off and are unable to secure employment. We argue that these necessity entrepreneurs will try to capitalize on their skills in their entrepreneurial endeavors by engaging in a path dependency entrepreneurial process. In particular, because they often accumulated their high levels of knowledge and skills in a given area (e.g., industry, occupation, function) we contend that they will want to utilize their specific human capital (e.g., Mincer \& Ofek, 1982) by applying it in the same area in which it was obtained.

At the opportunity identification stage, we argue that these necessity entrepreneurs will identify opportunities that are closely related to their experience base and specific skillset. For instance, a highly educated person who was an accountant prior to becoming unemployed would 
pursue an opportunity of self-employment in accounting services. Similarly, a necessity entrepreneur educated to be a scientist or a technician will strive to apply his or her scientific or technical skills in the venture that he or she creates. Such path dependent behavior (Aldrich \& Auster, 1986; David, 1985) traces to the developed environments and the differentiated market structures these necessity entrepreneurs are embedded in, as such settings enable them to pursue opportunities that match their high levels of human capital endowments. That is, in contrast to developing environments where path dependency behavior is severely constrained by low market demand, in more munificent developed environments, such behavior is encouraged.

Although necessity entrepreneurs in developed environments will seek to use their skills effectively while engaging in venture creation, given their urge to fulfill safety needs, they will nevertheless tend to identify simple ventures, such as solo-operated consulting businesses that offer services and products related to their expertise. In addition, at the exploitation stage, their urge to fulfill their basic safety needs will lead them to try to exercise control over their entrepreneurial fate (Kuechle et al., 2016) by starting up a small business in the domain in which they obtained education and experience. Our claims extend the idea that these individuals possess and capitalize on professional links within the market or industry where the opportunity is being exploited (Shane, 2000).

In short, thanks to the munificence of and refined market structures in developed environments, necessity entrepreneurs have some leeway to capitalize on their high levels of human capital as they engage in the entrepreneurial process, yet their urge to fulfill basic safety needs will tend to limit their ventures to simple ones that could provide basic financial security. Hence, we predict that these necessity entrepreneurs will engage in a path dependency 
entrepreneurial process that leverages their unique skillsets and past experience. Stated more formally, we propose that:

Proposition 4a: Under the condition of basic safety needs in a developed environment, necessity entrepreneurs with high levels of human capital will pursue a path dependency entrepreneurial process when supportive institutional levers are absent.

In line with our rationale above, we argue that the way that highly skilled necessity entrepreneurs in developed environments identify and exploit opportunities depends on whether institutional levers supportive of entrepreneurship exist. For example, through training and skill development provided by such levers, individuals have increased access to information, and are better able to interpret data with regard to opportunities in existing or latent markets - thus allowing them to pursue opportunities with more growth potential (Sarasvathy, Dew, Velamuri, \& Venkataraman, 2003; Townsend, Hunt, McMullen, \& Sarasvathy, 2018). At the same time, these necessity entrepreneurs nevertheless engage in a path dependency process that reflects their high levels of human capital endowments and the possibilities offered by heterogeneous market structures and munificent environments. We thus propose that they are likely to pursue an ambitious $^{6}$ path dependency entrepreneurial process.

Supportive institutional levers, such as the government programs described above, enable necessity entrepreneurs with high human capital endowments to utilize their skills in a more aspiring way. These levers do so in part by affording necessity entrepreneurs more time than they would otherwise have to consider how to best apply their skills in a given setting, and by offering these individuals financial support to develop ventures that should have strong growth prospects.

\footnotetext{
${ }^{6}$ We thank one of our reviewers for suggesting this term.
} 
Given their high skill levels, necessity entrepreneurs will have general awareness of the industry, occupation or function in which they obtained experience. Yet, rather than rushing to fulfill safety needs by establishing a simple venture in the settings in which they obtained expertise, supportive institutional levers will prime them to reflect on how to best employ their skills. For example, institutional levers may offer training in running a business, which should not only help these necessity entrepreneurs to consider a wider range of ventures within their areas of expertise, but also to enhance their knowledge of how to exploit them effectively. For instance, a study of formerly unemployed entrepreneurs in Germany reveals that those with high levels of human capital applied their skills to identify and open a variety of often sophisticated service (e.g., a web design firm) and product (e.g., construction engineering, custom glass manufacturing) businesses (Dencker et al., 2009a).

Thus, we propose that necessity entrepreneurs in this situation will seek to capitalize on their skills and engage in path dependent behaviors, but to do so in a more ambitious way than they would in the absence of supportive institutional levers. In sum, we contend that necessity entrepreneurs will allocate their high levels of education, experience and skills toward a growthoriented exploitation of opportunities that match their existing human capital endowments. Stated more formally, we propose that:

Proposition 4b: Under the condition of basic safety needs in a developed environment, necessity entrepreneurs with high levels of human capital will pursue an ambitious path dependency entrepreneurial process when supportive institutional levers are present.

\section{DISCUSSION}

We have argued that entrepreneurship theory should better account for variation in the widespread and growing phenomenon of necessity entrepreneurship, because the extant dichotomous approach that distinguishes simply between opportunity and necessity 
entrepreneurship is highly limitative and tends to downplay the richness of this phenomenon, and the differences and nuances of its processes. Grounded in seminal motivation theory, we reconceptualized the necessity entrepreneurship construct in order to move beyond the dichotomous approach, and thereby advance the view that entrepreneurial processes centered on opportunity identification and exploitation occur along all levels of needs. Specifically, by building on the boundary condition of fulfillment of an individual's basic needs, and by contextualizing our theory of necessity entrepreneurs' entrepreneurial processes (i.e., conditional on their level of human capital endowments and the environment in which they are embedded), our reconceptualization highlights the importance of previously neglected and under-theorized aspects of the heterogeneity inherent to necessity entrepreneurs and the processes by which they engage in entrepreneurship.

Building on this general advancement and the new perspective on necessity entrepreneurship that it entails, our study offers a number of other important insights for theory development in entrepreneurship, and beyond. First, our boundary condition of basic needs provides a promising basis for theory development on necessity entrepreneurship, as well as a theory-based lens through which necessity entrepreneurship can be more clearly defined, distinguished from, and compared with, entrepreneurial endeavors geared towards the fulfillment of higher-level needs. For example, given our focus on necessity entrepreneurship, we theorized about the first two levels of basic needs — physiological and safety — which complements past research examining the pursuit of higher-level needs in entrepreneurship (e.g., psychological and self-fulfillment needs, see McClelland, 1961). Similarly, our study highlights the relevance of existing concepts (e.g., opportunity creation and discovery) for examining necessity entrepreneurship, and suggests that such theories are more applicable in certain environments- 
and for certain types of necessity entrepreneurs. Specifically, their usefulness needs to be considered in the light of the level of needs an individual is urged to fulfill with a given skillset in a given context.

Second, our framework contributes novel insights to extant research on the critical need for the joint consideration of the individual and the context within which entrepreneurship occurs (Davis et al., 2009; Romanelli, 1991; Shepherd, 2011; Welter, 2011; Welter \& Smallbone, 2011). Yet, in contrast to the common focus on entrepreneurs with high levels of human capital who pursue opportunities to achieve higher-level needs, our theorizing posits that variation in human capital endowments have non-trivial effects on the entrepreneurial process and, importantly, that individuals with similar levels of human capital will engage in entirely different types of entrepreneurial processes when they are located in different environments. As such, our study suggests that, in the same way as necessity entrepreneurs may have high skills, other types of entrepreneurs may pursue opportunities with great eagerness and strong ambition, despite low skill levels. Moreover, it suggests that future research could take a fine-grained approach to the study of the effects of human capital — and possibly other types of capital endowments — on entrepreneurial activity, one that contextualizes entrepreneurs' endowments and assets.

Third, by discussing the role and importance of institutional levers that support the endeavors of necessity entrepreneurs in different contexts (Mair et al., 2012; McKague et al., 2015), our study advances a theory on necessity entrepreneurship that allows for institutional agency, thereby forging a close link between institutional research and the managerial and organizational literature. Specifically, our theory development extends research on the supportive role of institutions in helping individuals fulfill basic needs via new venture creation (e.g., Bruton, Ahlstrom, \& Li, 2010), to theorize about how the absence or presence of supportive 
institutional levers leads to starkly different entrepreneurial processes for otherwise similar necessity entrepreneurs. Our approach should further allow scholars to examine in a systematic way how key individual and environmental characteristics influence the entrepreneurial process. For instance, using the approach we set forth in this paper, scholars could theorize on how a national or regional culture supportive of entrepreneurship (Eesley, Eberhart, Skousen, \& Cheng, 2018) and other informal institutional domains (Uzo \& Mair, 2014) affect necessity entrepreneurship.

Finally, the insights presented in this article are of high relevance to policymakers and other institutional agents seeking to promote necessity entrepreneurship within their contexts. In this vein, not only do we offer theory on how institutional levers may affect and bolster entrepreneurial processes, but our contextualized approach allows also for novel ways to understand such levers, as these agents often do not have the opportunity to compare their approaches across contexts - that is, in our case, developing and developed environments. It seems that such insights will further increase in importance, not least because policymakers are challenged to address structural changes in job markets that are caused by technological advances (e.g., digitalization, artificial intelligence, robotization) and that render manifold job profiles obsolete (Goos, 2018). In effect, because necessity entrepreneurship implies a view on human beings that emphasizes their ability to contribute in creative and productive ways to a society by pursuing their own entrepreneurial activity, it offers an interesting perspective for policymakers in times when they fundamentally rethink existing policy approaches and experiment with new ones, including the granting of a basic income to entire populations.

\section{Limitations and Directions for Future Research}


Our framework is not without limitations. For example, our theorizing does not specifically account for part-time necessity entrepreneurship. Indeed, as necessity entrepreneurs are defined by negative push factors and have no other choice to make a living, one can assume that they try to engage in entrepreneurial activity full time. However, future research could study necessity entrepreneurs who, in addition to working in a low quality, unstable part-time job (e.g., washing cars) or seasonal work (e.g., harvesting crops, picking fruit), start their own ventures out of necessity to earn more income. Moreover, such activity is not necessarily inconsistent with our account, in that, for instance, one could consider these individuals as using their part-time employment to fulfill their physiological needs, and engaging in part-time entrepreneurship to fulfill their safety needs.

Additionally, given that our theorizing has focused on exploring the two most basic levels of need, it does not account for certain temporal aspects, such as the possibility that necessity entrepreneurs would, following successful entrepreneurial activities, transition from necessity to voluntary entrepreneurial activity in order to fulfill higher-level needs. For instance, by engaging in entrepreneurial activity in a consistent manner and gaining experience, it is possible that someone's skillset enriches over time. To the extent that such an individual generates enough income for his or her needs, he or she might build on these acquired skills to voluntarily engage in entrepreneurial activity. Our framework and theorizing could serve as a stepping stone for future research exploring when and how, once his or her lower-level needs are fulfilled, an entrepreneur may then transition to trying to fulfill higher-level needs.

Furthermore, our study offers a number of opportunities for scholars to extend our research conceptually, and to test our propositions empirically. A promising avenue in this regard would be to explore outcomes of the different entrepreneurial processes we have outlined. 
This follows from our discussion of the antecedents, processes and outcomes in our literature review section, which highlights the clear linkages between process and outcomes, as well as the critical lack of knowledge on necessity entrepreneurship for both of these stages of the entrepreneurial journey. By extending our theorizing and propositions, one can theorize about performance outcomes such as the failure rates of ventures (and reasons for such failures).

Similarly, the structural disadvantages that motivate individuals to seek fulfillment of basic needs come in many shapes. For example, age, gender, race, and religion may discriminate positively or negatively among individuals, even though they have the same levels of human capital endowments and are embedded in the same context. These different types of discrimination could lead to different entrepreneurial processes than those we proposed in this paper. For example, high skilled individuals experiencing age discrimination in a developed setting may find that such discrimination primarily influences their ability to get a job—due, for instance, to employers' fears about potential costs that would be borne — rather than their ability to sell their goods and services. In addition, gender and race discrimination arguably can have deleterious effects not just in hiring, but also in terms of potential customers.

Thus, a potential avenue for future research would be to explore both conceptually and empirically how disadvantages influence the entrepreneurial process, such as in terms of the types of opportunities that necessity entrepreneurs identify. In doing so, scholars may find it useful to explore effects of specific institutional levers that are targeted to groups that are disadvantaged in certain contexts (e.g., women, migrants, the disabled, the elderly or the youth) and focused on certain industries (Nikiforou et al., 2019; Ortlieb \& Weiss, 2015). For example, developing countries are replete with examples of corporate programs geared towards empowering women possessing some level of education by facilitating direct trade of 
manufactured consumer goods, such as Tupperware, cosmetics, vitamins, and other household products (Dolan \& Scott, 2009). The current refugee crisis might also be a rich source of entrepreneurial activity under the condition of basic needs and may give rise to different processes than those theorized above, conditional on refugees' levels of human capital endowments and the absence or presence of programs aiming to facilitate refugee entrepreneurship and integration (Sánchez Piñeiro, 2017).

Finally, scholars will face some challenges in testing our propositions empirically, such as the need to obtain data to assess opportunity types and entrepreneurial processes for necessity entrepreneurs with different levels of basic need. For example, available cross-country data sets tend to treat all necessity entrepreneurs as the same, which clearly limits exploration of our propositions. One approach that has been fruitful to date has been to examine necessity entrepreneurs in a developed environment through use of surveys (e.g., Dencker et al., 2009b), which would allow the comparison of entrepreneurial processes for individuals with low versus high human capital endowments. Studies such as these, however, do not allow for a comparison of the absence or presence of supportive institutional levers, let alone a comparison across developing and developed environments. Although knowledge gaps in the literature warrant extending such research to developing environments in order to obtain different representative samples of who necessity entrepreneurs are, such an undertaking is inherently challenging since, due to illiteracy rates in these contexts, data often need to be collected by hand. Nevertheless, such endeavors are critical for increasing our knowledge of necessity entrepreneurship, its processes and outcomes.

\section{CONCLUSION}


Necessity entrepreneurship is a prevalent phenomenon across many nations, both in the developed and developing parts of the world. We hope that our study, and particularly the refined and systematic theoretical understanding that it offers, will motivate scholars to conduct research projects that will strengthen and advance our knowledge about this important topic. Notably, such knowledge is required to help individuals overcome some of the adverse circumstances that they face while engaging in their entrepreneurial project, and to support governments and intermediary organizations alike in the design of policies and programs that can assist necessity entrepreneurs in the creation of their venture. It is our hope that our study also inspires policymakers and international development organizations seeking to help the skilled and unskilled unemployed apply their human capital by transitioning to entrepreneurial activities and, as such, escape conditions of basic needs. 


\section{REFERENCES}

Acs, Z. J., Desai, S., \& Hessels, J. 2008. Entrepreneurship, economic development and institutions. Small Business Economics, 31: 219-234.

Aguilera, R. A., \& Grøgaard, B. 2019. The dubious role of institutions in international business: A road forward. Journal of International Business Studies, 50: 20-35.

Aldrich, H., \& Auster, E. R. 1986. Even dwarfs started small: Liabilities of age and size and their strategic implications. In L. L. Cummings \& B. Staw (Eds.), Research in organizational behavior: 156-198. Greenwich, CT: JAI Press.

Alvarez, S. A., \& Barney, J. B. 2007. Discovery and creation: Alternative theories of entrepreneurial action. Strategic Entrepreneurship Journal, 1: 11-26.

Alvarez, S. A., \& Barney, J. B. 2014. Entrepreneurial opportunities and poverty alleviation. Entrepreneurship Theory and Practice, 38: 159-184.

Banerjee, A. V., \& Duflo, E. 2007. The economic lives of the poor. Journal of Economic Perspectives, 21: 141-168.

Barney, J. 1991. Firm resources and sustained competitive advantage. Journal of Management, 17: 99-120.

Becker, G. S. 1964. Human capital. Chicago, IL: University of Chicago Press.

Bergmann, H., \& Sternberg, R. 2007. The changing face of entrepreneurship in Germany. Small Business Economics, 28(2-3): 205-221.

BfE. 2004. Gründungen aus dem Jahr 2001. Büro für existenzgründungen, Munich.

Bhola, R., Verheul, I., Grilo, I., \& Thurik, A. R. 2006. Explaining engagement levels of opportunity and necessity entrepreneurs. Research report H200610. Zoetermeer: EIM Business and Policy Research. 
Binder, M., \& Coad, A. 2013. Life satisfaction and self-employment: A matching approach. Small Business Economics, 40: 1009-1033.

Block, J., Kohn, K., Miller, D., \& Ullrich, K. 2015. Necessity entrepreneurship and competitive strategy. Small Business Economics, 44: 37-54.

Block, J., \& Sandner, P. 2009. Necessity and opportunity entrepreneurs and their duration in selfemployment: Evidence from German micro data. Journal of Industry, Competition and Trade, 9: 117-137.

Block, J. H., \& Wagner, M. 2010. Necessity and opportunity entrepreneurs in Germany: Characteristics and earnings differentials. Schmalenbach Business Review, 62(2): 154-174.

Bradley, S. W., McMullen, J. S., Artz, K., \& Simiyu, E. M. 2012. Capital is not enough: Innovation in developing economies. Journal of Management Studies, 49: 684-717.

Bradley, S. W., McMullen, J. S., Atmadja, A., Simiyu, E., \& Artz, K. 2011. Self-employed or employing others? Pre-entry capabilities, entrepreneurial action, and the learned resourcefulness of microcredit firm founders. Frontiers of Entrepreneurship Research, 31: 2.

Brewer, J., \& Gibson, S. W. (Eds.). 2014. Necessity entrepreneurs: Microenterprise education and economic development. Cheltenham, UK: Edward Elgar Publishing.

Brockhaus, R. H. 1980. Risk taking propensity of entrepreneurs. Academy of Management Journal, 23: 509-520.

Bruton, G. D., Ahlstrom D., Li H.-L. 2010. Institutional theory and entrepreneurship: Where are we now and where do we need to move in the future? Entrepreneurship Theory Practice, 34: $421-440$.

Bruton, G. D., Ketchen, D. J., \& Ireland, R. D. 2013. Entrepreneurship as a solution to poverty. 
Journal of Business Venturing, 28: 683-689.

Caliendo, M., \& Kritikos, A. S. 2010. Start-ups by the unemployed: Characteristics, survival and direct employment effects. Small Business Economics, 35: 71-92.

Campos, F., Frese, M., Goldstein, M., Iacovone, L., Johnson, H. C., McKenzie, D., \& Mensmann, M. 2017. Teaching personal initiative beats traditional training in boosting small business in West Africa. Science, 357: 1287-1290.

Cappelli, P., Bassi, L., Katz, K., Knoke, D., Osterman, P., \& Useem, M. (Eds.). 1997. Change at work. New York, NY: Oxford University Press.

Carsrud, A., \& Brännback, M., 2011. Entrepreneurial motivations: What do we still need to know? Journal of Small Business Management, 49: 9-26.

Charman, A. J., \& Petersen, L. M. 2017. Temporal and spatial enterprise change in a township informal economy: A resurvey of micro-enterprises in Delft South. REDI3x3 Working Paper 26, University of Cape Town, South Africa.

Choi, Y. R., Lévesque, M., \& Shepherd, D.A. 2008. When should entrepreneurs expedite or delay opportunity exploitation? Journal of Business Venturing, 23: 333-355.

Chliova, M., Brinckmann, J., \& Rosenbusch, N. 2015. Is microcredit a blessing for the poor? A meta-analysis examining development outcomes and contextual considerations. Journal of Business Venturing, 30(3): 467-487.

David, P. A. 1985. Clio and the economics of QWERTY. American Economic Review, 75: 332337.

Davidsson, P., \& Honig, B. 2003. The role of social and human capital among nascent entrepreneurs. Journal of Business Venturing, 18: 301-331.

Davis, J. P., Eisenhardt, K. M., \& Bingham, C. B. 2009. Optimal structure, market dynamism, 
and the strategy of simple rules. Administrative Science Quarterly, 54: 413-452.

Dencker, J. C. 2012. Who do firms lay off and why? Industrial Relations, 51: 152-169.

Dencker, J. C., \& Gruber, M. 2015. The effects of opportunities and founder experience on new firm performance. Strategic Management Journal, 36: 1035-1052.

Dencker, J. C., Gruber, M., \& Shah, S. 2009a. Pre-entry knowledge, learning, and the survival of new firms. Organization Science, 20: 516-537.

Dencker, J. C., Gruber, M., \& Shah, S. 2009b. Individual and opportunity factors influencing job creation in new firms. Academy of Management Journal, 52: 1125-1147.

Dolan, C., \& Scott, L. 2009. Lipstick evangelism: Avon trading circles and gender empowerment in South Africa. Gender \& Development, 17: 203-218.

Dutt, N., Hawn, O., Vidal, E., Chatterji, A., McGahan, A., \& Mitchell, W. 2016. How open system intermediaries address institutional failures: The case of business incubators in emerging-market countries. Academy of Management Journal, 59(3): 818-840.

Eesley, C. E., Eberhart, R. N., Skousen, B. R., \& Cheng, J. 2018. Institutions and entrepreneurial activity: The interactive influence of misaligned formal and informal institutions. Strategy Science, 3: 393-407.

Evans, D., \& Leighton, L. 1989. Some empirical aspects of entrepreneurship. American Economic Review, 79: 519-535.

Festinger, L. 1957. A theory of cognitive dissonance. Evanston, IL: Row, Peterson. Freud, S. 1924. A general introduction to psychoanalysis. New York, NY: Permabooks. Gagné, R. M., \& Glaser R. 1987. Foundations in learning research. In R. M. Gagné (Ed.), Instructional technology: Foundations: 49-83. Hillsdale, NJ: Lawrence Erlbaum. Galbraith, J. R. 1977. Organization Design. Reading, UK: Addison-Wesley. 
Gartner, W. B. 1985. A conceptual framework for describing the phenomenon of new venture creation. Academy of Management Review, 10: 696-706.

Giacomin, O., Guyot, J. L., Janssen, F., \& Lohest, O. 2011. Opportunity and/or necessity entrepreneurship? The impact of the socio-economic characteristics of entrepreneurs, Munich Personal RePEc Archive Paper no. 29506, University of Munich, Germany.

Giacomin, O., Janssen, F., \& Shinnar, R. 2018. Dichotomie nécessité et opportunité: Retour aux origines. 7èmes Journées Georges Doriot, Montréal, Canada.

Gilad, B., \& Levine, P. 1986. A behavioral model of entrepreneurial supply. Journal of Small Business Management, 24: 45-53.

Goos, M. 2018. The impact of technological progress on labour markets: Policy challenges. Oxford Review of Economic Policy, 34: 362-375.

Gruber, M. 2010. Exploring the origins of organizational paths: Empirical evidence from newly founded firms. Journal of Management, 36: 1143-1167.

Haas, M., \& Vogel, P. 2016. Supporting the transition from unemployment to selfemployment - A comparative analysis of governmental support programs across Europe. In J. Brewer \& S. W. Gibson (Eds.), Institutional case studies on necessity entrepreneurship: 3-38. Northampton, MA: Edward Elgar Publishing.

Hall, J., Matos, S., Sheehan, L., \& Silvestre, B. 2012. Entrepreneurship and innovation at the base of the pyramid: A recipe for inclusive growth or social exclusion? Journal of Management Studies, 49: 785-812.

Hanson, G., Liu, C., \& McIntosh, C. 2017. The rise and fall of US low-skilled immigration. National Bureau of Economic Research, No. w23753.

Helms, B. 2006. Access for all: Building inclusive financial systems. The World Bank. 
Institut für Mittelstandsforschung, 2005. Statistik zu gründungen aus der arbeitslosigkeit. www.fm-bonn.org.

Karlan, D., \& Valdivia, M. 2011. Teaching entrepreneurship: Impact of business training on microfinance clients and institutions. Review of Economics and Statistics, 93: 510-527.

Karnani, A. 2007. The mirage of marketing to the bottom of the pyramid: How the private sector can help alleviate poverty. California Management Review, 49: 90-111.

Khavul, S. 2010. Microfinance: Creating opportunities for the poor? Academy of Management Perspectives, 24: 58-72.

Kirzner, I. M. 1973. Competition and entrepreneurship. Chicago, IL: University of Chicago Press.

Kistruck, G., Webb, J. W., Sutter, C. J., \& Ireland, R. D. 2011. Microfranchising in base-of-thepyramid markets: Institutional challenges and adaptations to the franchise model. Entrepreneurship Theory and Practice, 35: 503-531.

Kolk, A., Rivera-Santos, M., \& Rufín, C. 2014. Reviewing a decade of research on the “base/bottom of the pyramid" (BOP) concept. Business \& Society, 53: 338-377.

Kuechle, G., Boulu-Reshef, B., \& Carr, S. D. 2016. Prediction-and control-based strategies in entrepreneurship: The role of information. Strategic Entrepreneurship Journal, 10: 43-64.

Lazear, E., 2005. Entrepreneurship. Journal of Labor Economics, 23: 649-680.

Maas, G., \& Herrington, M. 2006. Global Entrepreneurship Monitor: South African report. Graduate School of Business. Cape Town: University of Cape Town.

Mair, J., \& Martí, I., 2009. Entrepreneurship in and around institutional voids: A case study from Bangladesh. Journal of Business Venturing, 24: 419-435.

Mair, J., Martí, I., \& Ventresca, M. J., 2012. Building inclusive markets in rural Bangladesh: 
How intermediaries work institutional voids. Academy of Management Journal, 55: 819850.

Maslow, A. H. 1943. A theory of human motivation. Psychological Review, 50: 370-396.

Maslow, A. H. 1954. Motivation and Personality. New York, NY: Harper and Row.

Matin, I., Hulme, D., \& Rutherford, S. 2002. Finance for the poor: From microcredit to microfinancial services. Journal of International Development, 14: 273-294.

McClelland, D. C. 1961. The achievement society. Princeton, NJ: Von Nostrand.

McClelland, D. C. 1987. Human motivation. CUP Archive.

McKague, K., Zietsma, C., \& Oliver, C. 2015. Building the social structure of a market. Organization Studies, 36: 1063-1093.

McMullen, J. S., Bagby, D. R., \& Palich, L. E. 2008. Economic freedom and the motivation to engage in entrepreneurial action. Entrepreneurship Theory and Practice, 32: 875-895.

Mincer, J., \& Ofek, H. 1982. Interrupted work careers: Depreciation and restoration of human capital. Journal of Human Resources, 17: 3-24.

Morduch, J. 2000. The microfinance schism. World Development, 28(4): 617-629.

Mostafa, R., \& Klepper, S. 2013. Industrial development through tacit knowledge seeding: Evidence from the Bangladesh garment industry. London, ON: Ivey School of Business.

Murray, H. A. 1938. Explorations in personality. New York, NY: Oxford University Press.

Naudé, W. 2010. Entrepreneurship, developing countries, and development economics: New approaches and insights. Small Business Economics, 34: 1-12.

Neher, A. 1991. Maslow's theory of motivation: A critique. Journal of Humanistic Psychology, 31: 89-112. 
Nikiforou, A., Dencker, J. C., \& Gruber, M. 2019. Necessity entrepreneurship and industry choice in new firm creation. Working Paper, DTU/Northeastern/EPFL.

North, D. C. 1990. Institutions, institutional change economic performance. Cambridge, UK: Cambridge University Press.

Ortlieb, R., \& Weiss, S. 2015. Business start-ups and youth self-employment in Germany: A policy literature review. STYLE Working Papers, WP7.1/DE. CROME, Brighton, UK: University of Brighton. http://www.style-research.eu/publications/working-papers

Pelled, L. H. 1996. Demographic diversity, conflict, and work group outcomes: An intervening process theory. Organization Science, 7: 615-631.

Poschke, M. 2013. Entrepreneurs out of necessity: A snapshot. Applied Economics Letters, 20: $658-663$.

Prahalad, C. K. 2006. The fortune at the bottom of the pyramid. Pearson Education India.

Reynolds, P. D. 2012. Entrepreneurship in developing economies: The bottom billions and business creation. Foundations and Trends in Entrepreneurship, 8: 141-277.

Ritsilä, J., \& Tervo, H. 2002. Effects of unemployment on new firm formation: Micro-level panel data evidence from Finland. Small Business Economics, 19: 31-40.

Romanelli, E. 1991. The evolution of new organizational forms. Annual Review of Sociology, 17: 79-103.

Rosling, H., Rosling, O., \& Rosling-Ronnlund, A. 2018. Factfulness: Ten reasons we're wrong about the world —and why things are better than you think. New York, NY: Flatiron Books.

Sánchez Piñeiro, O. M. 2017. How business incubators can facilitate refugee entrepreneurship and integration. United Nations High Commissioner for Refugees, April 28, 2017: 
https://www.unhcr.org/innovation/how-we-can-use-business-incubators-for-refugeeintegration.

Santarelli, E., \& Vivarelli M. 2007. Entrepreneurship and the process of firms' entry, survival, and growth. Industrial and Corporate Change, 16: 455-488.

Sarasvathy, S. D., Dew, N., Velamuri, S. R., \& Venkataraman, S. 2003. Three views of entrepreneurial opportunity. In Z. J. Acs \& D. B. Audretsch (Eds.), Handbook of entrepreneurship research: 141-160. Boston, MA: Springer.

SCB. 1994. Nyfo"retagandet i sverige 1992 och 1993 [New firm formation in Sweden in 1992 and 1993]. Orebro: SCB Publishing Unit.

Seelos, C., Mair, J. 2007. Profitable business models and market creation in the context of deep poverty: A strategic view. Academy of Management Perspectives, 21: 49-63.

Shane, S. 2000. Prior knowledge and the discovery of entrepreneurial opportunities. Organization Science, 11: 448-470.

Shane, S. 2003. A general theory of entrepreneurship: The individual-opportunity nexus. Cheltenham, UK: Edward Elgar Publishing.

Shane, S. 2009. Why encouraging more people to become entrepreneurs is bad public policy. Small Business Economics, 33: 141-149.

Shane, S., \& Venkataraman, S. 2000. The promise of entrepreneurship as a field of research. Academy of Management Review, 25: 217-226.

Shapero, A. 1975. The displaced, uncomfortable entrepreneur. Psychology Today, November 1975.

Shapero, A. 1984. The entrepreneurial event. In C. A. Kent (Ed.), The environment for entrepreneurship. Lexington, MA: Lexington Books. 
Shapero, A., \& Sokol, L. 1982. The social dimensions of entrepreneurship. In C. Kent, D. Sexton \& K. Vesper (Eds.), Encyclopaedia of entrepreneurship: 72-90. Englewood Cliffs, NJ: Prentice-Hall.

Shepherd, D. A. 2011. Multilevel entrepreneurship research: Opportunities for studying entrepreneurial decision making. Journal of Management, 37: 412-420.

Sirmon, D. G., Hitt, M. A., \& Ireland, R. D. 2007. Managing firm resources in dynamic environments to create value: Looking inside the black box. Academy of Management Review, 32: 273-292.

Sutter, C., Bruton, G. D., \& Chen, J. 2018. Entrepreneurship as a solution to extreme poverty: A review and future research directions. Journal of Business Venturing, doi: https://doi.org/10.1016/j.jbusvent.2018.06.003.

Tobias, J. M., Mair, J., \& Barbosa-Leiker, C. 2013. Toward a theory of transformative entrepreneuring: Poverty reduction and conflict resolution in Rwanda's entrepreneurial coffee sector. Journal of Business Venturing, 28: 728-742.

Townsend, D., Hunt, R., McMullen, J. S., \& Sarasvathy, S. 2018. Uncertainty, knowledge problems, and entrepreneurial action. Academy of Management Annals, 12: 659-687.

Ucbasaran, D., Westhead, P., \& Wright, M. 2008. Opportunity identification and pursuit: Does an entrepreneur's human capital matter? Small Business Economics, 30: 153-173.

Ucbasaran, D., Westhead, P., \& Wright, M. 2009. The extent and nature of opportunity identification by experienced entrepreneurs. Journal of Business Venturing, 24: 99-115.

Unger, J. M., Rauch, A., Frese, M., \& Rosenbusch, N. 2011. Human capital and entrepreneurial success: A meta-analytical review. Journal of Business Venturing, 26: 341-358.

Uzo, U., \& Mair, J. 2014. Source and patterns of organizational defiance of formal institutions: 
Insights from Nollywood, the Nigerian movie industry. Strategic Entrepreneurship Journal, 8: 56-74.

Vaghely, I. P., \& Julien, P. A. 2010. Are opportunities recognized or constructed?: An information perspective on entrepreneurial opportunity identification. Journal of Business Venturing, 25: 73-86.

Venkataraman, H., Vermeulen, P., Raaijmakers, A., \& Mair, J. 2016. Market meets community: Institutional logics as strategic resources for development work. Organization Studies, 3: $709-733$.

Vivarelli, M. 2013. Is entrepreneurship necessarily good? Microeconomic evidence from developed and developing countries. Industrial and Corporate Change, 22: 1453-1495.

Webb, J. W., Bruton, G. D., Tihanyi, L., \& Ireland, R. D. 2013. Research on entrepreneurship in the informal economy: Framing a research agenda. Journal of Business Venturing, 28: 598614.

Webb, J. W., Tihanyi, L., Ireland, R. D., \& Sirmon, D. G. 2009. You say illegal, I say legitimate: Entrepreneurship in the informal economy. Academy of Management Review, 34: 492-510. Webb, P., \& Fairbourne, J. 2016. Microfranchising: A solution to necessity entrepreneurship. In J. Brewer \& S. W. Gibson (Eds.), Institutional case studies on necessity entrepreneurship: 195-225. Northampton, MA: Edward Elgar Publishing.

Welter, F., 2011. Contextualizing entrepreneurship: Conceptual challenges and ways forward. Entrepreneurship Theory and Practice, 35: 165-184.

Welter, F., \& Smallbone, D. 2011. Institutional perspectives on entrepreneurial behavior in challenging environments. Journal of Small Business Management, 49: 107-125.

Wennekers, S., Van Stel, A., Thurik, R., \& Reynolds, P. D. 2005. Nascent entrepreneurship and 
the level of economic development. Small Business Economics, 24: 293-309. 


\section{FIGURE 1a}

A Contextualized Framework of Entrepreneurial Processes

\section{Under the Condition of Basic Physiological Needs in Developing Environments}

\section{$\underline{\text { Human Capital }}$}

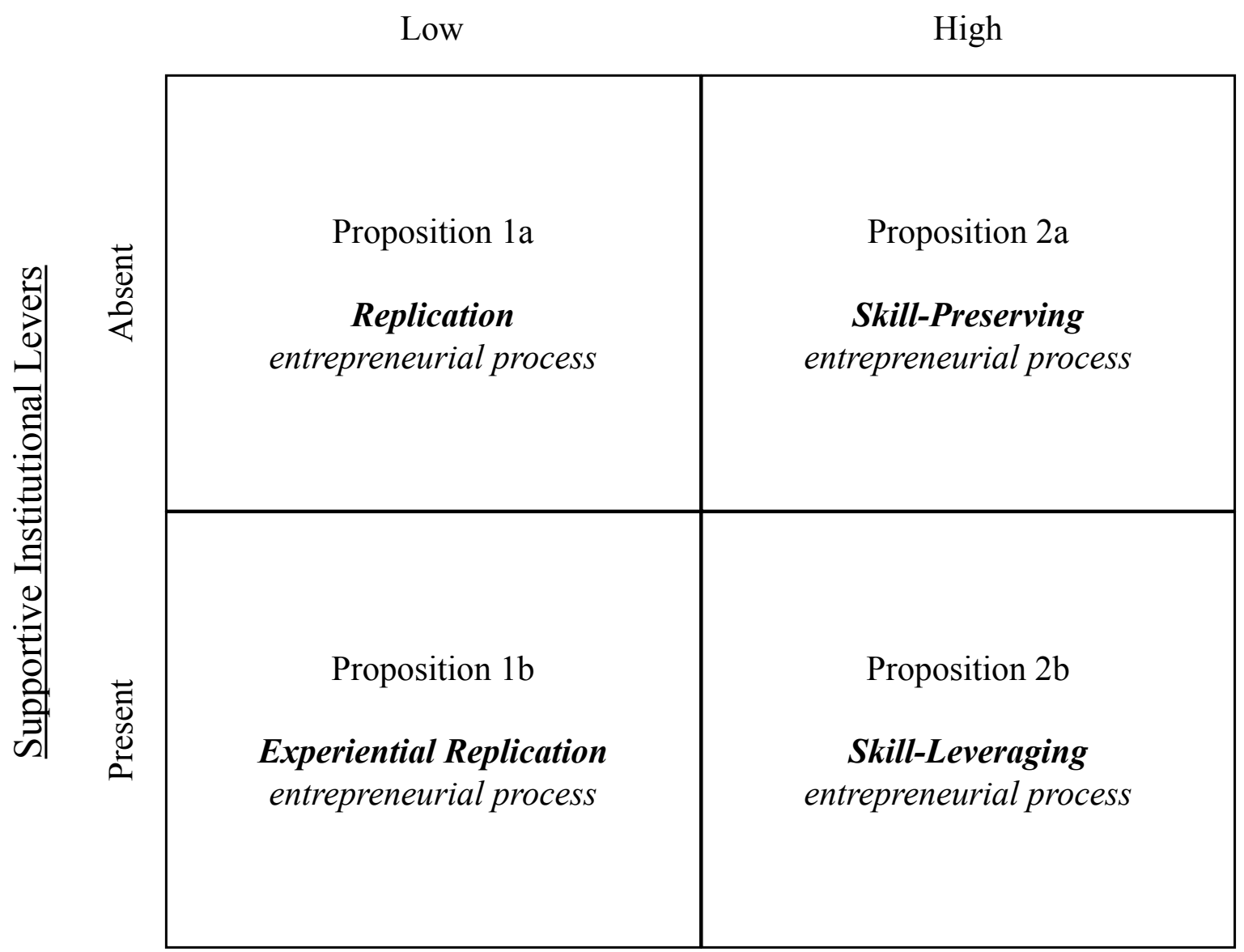


FIGURE 1b

A Contextualized Framework of Entrepreneurial Processes

Under the Condition of Basic Safety Needs in Developed Environments

$\underline{\text { Human Capital }}$

Low

High

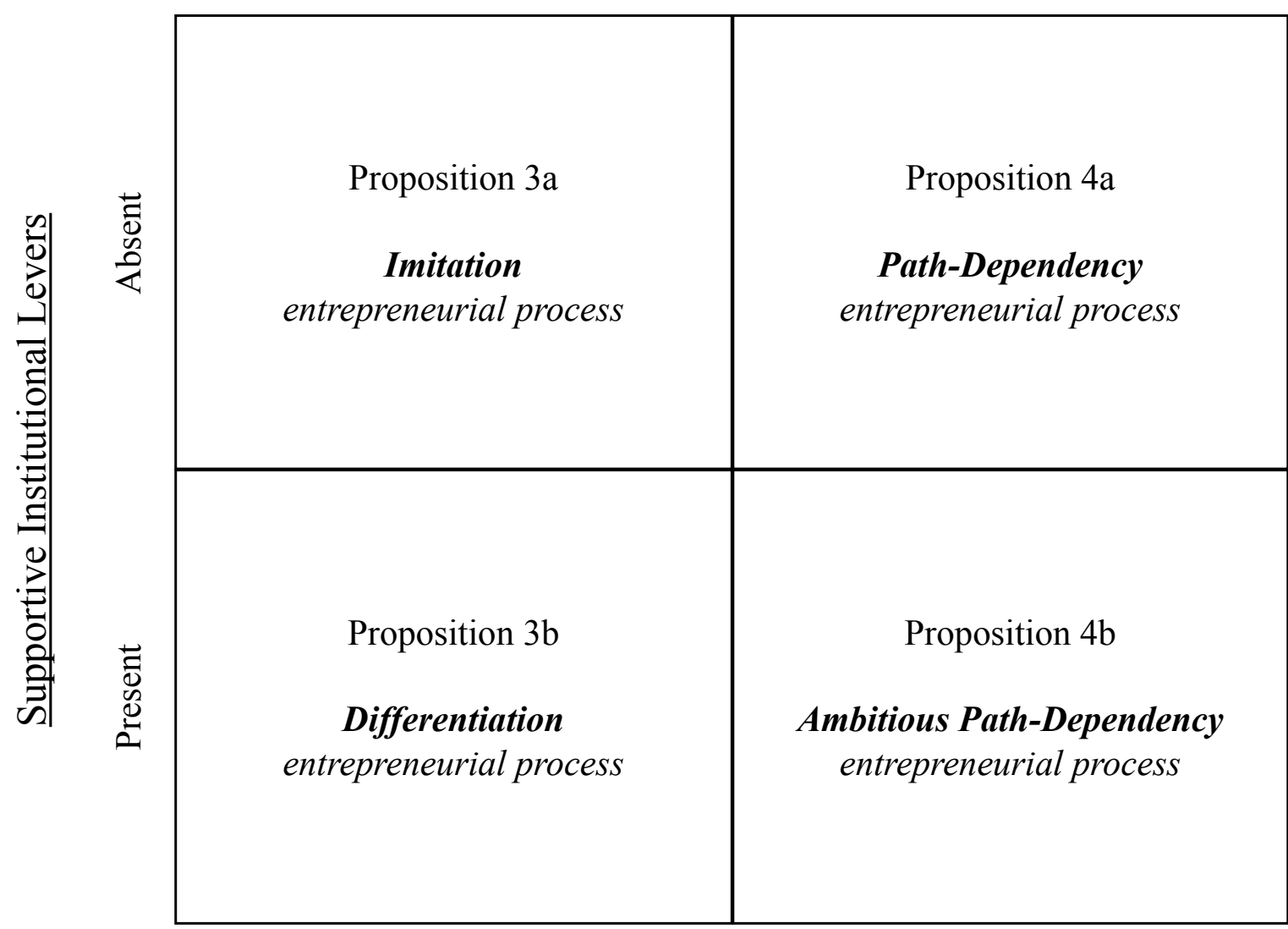




\section{Author Biographies}

John Dencker (j.dencker@northeastern.edu) is a professor of management and organizational development at the D'Amore-McKim School of Business, Northeastern University. He received his $\mathrm{PhD}$ in sociology from Harvard University. His research examines necessity entrepreneurship, the effects of corporate restructuring on the employment relationship, and workforce generational dynamics.

Sophie Bacq (s.bacq@northeastern.edu) is a Thomas E. Moore Faculty Fellow and assistant professor of entrepreneurship and innovation at Northeastern University D'Amore-McKim School of Business. She received her $\mathrm{PhD}$ in management from the Université catholique de Louvain. Her research centers on social entrepreneurship, societal impact, and the governance of hybrid organizations.

Marc Gruber (marc.gruber@epfl.ch) is a professor of management at the College of Management of Technology, Ecole Polytechnique Fédérale de Lausanne (EPFL). He received his $\mathrm{PhD}$ in management from the University of St. Gallen. His research examines entrepreneurship, strategic management, and the commercialization of technology.

Melvin Haas (melvin.haas@me.com) is a sales manager at Asyril SA. He received his Phd in Management from the Ecole Polytechnique Fédérale de Lausanne (EPFL). His research examines necessity entrepreneurship. 